\title{
EFEKTIVITAS PELAKSANAAN PERKULIAHAN JARAK JAUH BAGI MAHASISWA PLS/DIKMAS SEMESTER GENAP TAHUN AKADEMIK 20I9/2020
}

\section{Effectiveness Of The Implementation Of Distance Education For Students From Out Of School Education In Even Semester Of Academic Year 2019/2020}

\section{Saiffullah Darlan*}

Universitas Muhammadiyah

Palangkaraya, Palangka Raya,

Central Kalimantan, Indonesia

*email:

fuldarlan@gmail.com

\section{Kata Kunci:}

Kebijakan pemerintah, efektivitas perkuliahan, kualitas lulusan perguruan tinggi.

\section{Keywords:}

Government policies, lecture authority, quality of college graduates.

\begin{abstract}
Abstrak
Penelitian ini bertujuan untuk mendeskripsikan efektivitas pelaksanaan perkuliahan jarak jauh sistem daring semasa pandemi Covid-19 bagi mahasiswa program studi Pendidikan Luar Sekolah (Pendidikan Masyarakat) FKIP Universitas Palangka Raya setelah adanya kebijakan pemerintah agar dosen mengajar jarak jauh di rumah menggunakan sistem daring.

Penelitian dilakukan dengan metode kualitatif, informan penelitian terdiri dari dosen dan mahasiswa sebagai sumber data primer, serta data sekunder berupa dokumen dan nilai hasil tugas yang diberikan dosen kepada mahasiswa. Analisis data dilakukan secara simultan terus-menerus dari awal sampai akhir penelitian mulai pengumpulan data, kondensasi data, penampilan data, verifikasi dan kesimpulan.

Hasil penelitian bahwa pelaksanaan perkuliahan jarak jauh dengan menggunakan sistem daring bagi mahasiswa Pendidikan Luar Sekolah (Pendidikan Masyarakat) banyak menemukan hambatan dan tidak efektif, ini dikarenakan mahasiswa yang berada di desa kesulitan menerima materi kuliah yang disebabkan luasnya wilayah Kalimantan Tengah dan sulitnya mendapatkan sinyal internet serta kesulitan biaya membeli paket data.
\end{abstract}

\begin{abstract}
Penelitian ini bertujuan untuk mendeskripsikan efektivitas pelaksanaan perkuliahan jarak jauh sistem daring semasa pandemi Covid-19 bagi mahasiswa program studi Pendidikan Luar Sekolah (Pendidikan Masyarakat) FKIP Universitas Palangka Raya setelah adanya kebijakan pemerintah agar dosen mengajar jarak jauh di rumah menggunakan sistem daring.

Penelitian dilakukan dengan metode kualitatif, informan penelitian terdiri dari dosen dan mahasiswa sebagai sumber data primer, serta data sekunder berupa dokumen dan nilai hasil tugas yang diberikan dosen kepada mahasiswa. Analisis data dilakukan secara simultan terus-menerus dari awal sampai akhir penelitian mulai pengumpulan data, kondensasi data, penampilan data, verifikasi dan kesimpulan.

Hasil penelitian bahwa pelaksanaan perkuliahan jarak jauh dengan menggunakan sistem daring bagi mahasiswa Pendidikan Luar Sekolah (Pendidikan Masyarakat) banyak menemukan hambatan dan tidak efektif, ini dikarenakan mahasiswa yang berada di desa kesulitan menerima materi kuliah yang disebabkan luasnya wilayah Kalimantan Tengah dan sulitnya mendapatkan sinyal internet serta kesulitan biaya membeli paket data.
\end{abstract}

\section{Accepted}

September 2020

Published

December 2020
(C) 2020 The Authors. Published by Institute for Research and Community Services Universitas Muhammadiyah Palangkaraya. This is Open Access article under the CC-BY-SA License (http://creativecommons.org/licenses/by-sa/4.0/). DOI: https://doi.org//0.33084/anterior.vl8i2.456.

\section{PENDAHULUAN}

Tridharma yang diemban pada perguruan tinggi adalah menyelenggarakan pendidikan dan pengajaran, penelitian, dan pengabdian kepada masyarakat, ketiga dharma ini dilaksanakan secara simultan. Namun yang menjadi poin penting dan paling nampak pada sebuah perguruan tinggi harus melaksanakan dharma pertama pendidikan dan pengajaran yaitu menyelenggarakan pendidikan secara efektif, profesional dan berkualitas sehingga 
pada akhirnya menghasilkan lulusan (output) unggul, memiliki kreatifas, berjiwa inovatif, mandiri dan dapat bersaing diselaga lapangan pekerjaan. Karena pendidikan ini sangat penting maka siapapun tanpa kecuali orang berhak untuk mendapatkannya, karena pendidikan merupakan hak warganegara termasuk juga untuk mendapatkan pendidikan di perguruan tinggi. Dalam UUD 1945 Pasal $28 \mathrm{C}$ ayat (I) mengamanatkan bahwa "Setiap orang berhak mengembangkan diri melalui pemenuhan kebutuhan dasarnya, berhak mendapat pendidikan dan memperoleh manfaat dari ilmu pengetahuan dan teknologi, seni dan budaya, demi meningkatkan kualitas hidupnya dan demi kesejahteraan umat manusia”.

Namun sejak merebaknya pandemi Corona Virus Disease (Covid-19) sejak tahun 2019 di seluruh dunia termasuk juga Indonesia telah membuyarkan semua perencanaan dalam program penyelenggaraan pendidikan. Pendidikan adalah usaha sadar dan terencana untuk mewujudkan suasana belajar dan proses pembelajaran agar peserta didik secara aktif mengembangkan potensi dirinya untuk memiliki kekuatan spiritual keagamaan, pengendalian diri, kepribadian, kecerdasan, akhlak mulia, serta keterampilan yang diperlukan dirinya, masyarakat, bangsa dan negara. (UU RI. No. 20 Tahun 2003).

Karena penyelenggaraan pendidikan harus betul-betul dilaksanakan secara terencana dan profesional mulai dari input, proses, output dan pada akhirnya sampai pada uotcome. Input merupakan modal awal masukan kasar dimana setiap tahun lulusan Sekolah Menengah Atas mendaftar untuk menjadi calon mahasiswa untuk dapat diterima belajar di perguruan tinggi. Proses merupakan kegiatan utama dalam pelaksanaan pembelajaran yang terdiri dari pemberian teori, praktek, latihan dan evaluasi kepada mahasiswa untuk merealisasikan perencanaan yang telah disusun untuk mencapai lulusan yang berkualitas. Output merupakan hasil/lulusan dari suatu proses penyelenggaraan pendidikan yang telah dilaksanakan selama empat tahun di perguruan tinggi. Sedangkan outcame merupakan hasil/lulusan dari perguruan tinggi berkualitas, unggul dan dapat bersaing baik itu sesama lulusan perguruan tinggi maupun dalam dunia kerja.

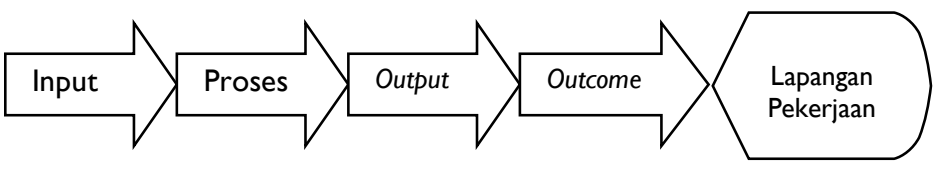

Gambar: Alur Proses Pendidikan

Pada semester genap Tahun Akademik 2019/2020 sejak adanya pandemi Corona Virus Disease (Covid-19), pelaksanaan pembelajaran di perguruan tinggi tidak dapat dilaksanakan secara normal sebagaimana yang sudah direncanakan. Dikutip pada jurnal Kompas.com 16 Juni 2020.10.30 Wib Menteri Pendidikan dan Kebudayaan (Mendikbud) Nadiem Makarim mengatakan, pembelajaran di perguruan tinggi pada semua zona masih wajib dilaksanakan secara daring hingga ada kebijakan lebih lanjut. Adanya alasan keselamatan yang dinomor satukan maka anjuran untuk melaksanakan pembelajaran secara daring disemua perguruan tinggi ini, suka tidak suka harus diikuti dan tentu menimbulkan banyak perubahan dalam sistem pembelajaran yang biasa dilakukan dengan cara tatap muka, berubah menjadi belajar jarak jauh dilakukan secara online. Anjuran pemerintah melakukan pembelajaran sistem daring ini tidak lain adalah untuk menghindari terjadinya kontak pisik, baik itu antara dosen dengan mahasiswa, maupun antara mahasiswa dengan mahasiswa pada saat kuliah sehingga perlu tinggal di rumah dan menjaga jarak fisik dan sosial (stay at home and, physical and social distancing).

Namun model baru pembelajaran jarak jauh dengan sistem daring ini bagi mahasiswa tentu membutuhkan kesiapan, baik itu penguasaan internet maupun biaya untuk membeli paket data. Walaupun banyak alternatif aplikasi dapat digunakan untuk melaksanakan pembelajaran online ini, diantaranya menggunakan berbagai aplikasi seperti zoom, google meet dan aplikasi lainnya sehingga dengan menggunakan perangkat ini dosen tidak bisa lagi berinteraksi tatap muka secara langsung kepada mahasiswanya, yang dikarenakan dosen mengajar dari rumah dan mahasiswa pun menerima materi kuliah di rumah. Diana Novita dan Addiestya Rosa Hutasuhut, (2020) bahwa Sistem Pembelajaran Daring atau SPADA adalah 
implementasi Pendidikan Jarak Jauh pada Pendidikan Tinggi yang bertujuan untuk meningkatkan pemerataan akses terhadap pembelajaran yang bermutu. Dengan sistem pembelajaran daring, SPADA Indonesia memberikan peluang bagi mahasiswa dari satu perguruan tinggi tertentu untuk dapat mengikuti suatu mata kuliah bermutu tertentu dari perguruan tinggi lain dan hasil belajarnya dapat diakui sama oleh perguruan tinggi dimana mahasiswa tersebut.

Demikian pula menurut Husamah (20I5); dikutip Khasanah, dkk (2020) bahwa secara umum, pembelajaran tatap muka memiliki berbagai kelebihan terhadap pengajar maupun peserta didik, antara lain: I. Disiplin formal yang diterapkan pada pembelajaran tatap muka dapat membentuk disiplin mental; 2. Memudahkan pemberian penguatan (reinforcement) dengan segera; 3. Memudahkan proses penilaian oleh pengajar; 4. Menjadi wahana belajar berinteraksi terhadap peserta didik. Kelebihan lainnya yaitu kemampuan sosialisasi antara dosen/tutor dengan mahasiswa, maupun antar sesama teman. Tidak hanya itu saja, dosen dapat mengamati secara langsung sikap dan tingkah laku mahasiswa dalam menerima materi.

Fenomena ini menarik untuk dicermati, apakah kebijakan yang dibuat pemerintah pembelajaran jarak jauh dengan sistem daring ini, dosen mengajar dari rumah kepada para mahasiswanya sudah efektif ataukah sebaliknya. Atas dasar itulah peneliti tertarik untuk mengkaji melalui suatu penelitian terutama bagi dosen dan mahasiswa Pendidikan Luar Sekolah/Pendidikan Masyarakat Fakultas Keguruan dan Ilmu Pendidikan Universitas Palangka Raya, dengan rumusan masalah bagaimana efektivitas pelaksanaan pembelajaran menggunakan sistem daring semasa Covid-19 bagi mahasiswa Pendidikan Luar Sekolah/Pendidikan Masyarakat (PLS /Dikmas) Fakultas Keguruan dan IImu Pendidikan Universitas Palangka Raya.

\section{METODE PENELITIAN}

Penelitian ini dilaksanakan pada Universitas Palangka Raya sebagai subjek penelitian adalah dosen dan mahasiswa program studi Pendidikan Luar Sekolah (PLS)/ Pendidikan Masyarakat (Dikmas) Fakultas Keguruan dan Ilmu Pendidikan. Agar mudah memperoleh data secara keseluruhan (holistik) dan mendalam mengenai pelaksanaan pembelajaran dengan menggunakan sistem daring ini, dan megingat karakteristik informan yang ada maka penelitian ini lebih tepat menggunakan pendekatan kualitatif. Pertimbangan peneliti menggunakan pendekatan kualitatif adalah ... metode kulaitatif dapat digunakan untuk mengungkap dan memahami sesuatu di balik fenomena yang sedikit pun belum diketahui. (Strauss dan Corbin, 2017).

Teknik yang digunakan untuk menjaring dan menghimpun data yang diperoleh dari dosen dan mahasiswa serta sumber lain yang relevan, maka peneliti mengikuti teknik yang dianjurkan Creswell (2017), dilakukan melalui observasi (observation), wawancara (interview), dan dokumentasi (documents).

Analisis data dilakukan secara terus menerus dari awal sampai akhir penelitian dan dilaksanakan secara lengkap terhadap seluruh data yang dikumpulkan. Pelaksanaan analisis data mengikuti prosedur penelitian kualitatif, yang dikemukakan Miles, Huberman dan Saldana, (20I4) mulai dari (I) condensasi data (Data Condensation), penampilan data (Data Display), dan (3) verifikasi dan kesimpulan. (Conclusions:Drawing and Verifying.

Selanjutnya untuk mengecek keabsahan data, dan untuk memastikan apakah data yang didapatkan dari informan itu benar-benar akurat, peneliti mengambil tiga dari tujuh prosedur yang dianjurkan oleh Lincoln dan Guba (1985) terdiri dari: I) ketekunan pengamatan, triangulasi, dan pengecekan sejawat.

\section{HASIL DAN PEMBAHASAN}

I. Profil Mahasiswa

$$
\text { Mahasiswa program studi PLS }
$$

(Dikmas) Fakultas Keguruan dan IImu Pendidikan Universitas Palangka Raya berasal dari berbagai daerah seperti Jawa, Sulawesi, Sumatera dan Kalimantan. Bagi mahasiswa dari Kalimantan itu sendiri 75 persen berasal dari desa yang tersebar di seluruh daerah provinsi Kalimantan Tengah. Data pada Badan Pusat Statistik Kalimantan Tengah tahun 2019 bahwa luas wilayah Kalimantan Tengah adalah I53.564,5 km2 atau 8,04 persen dari luas Indonesia. Wilayah administrasinya dibagi menjadi tiga belas kabupaten dan satu kota. (BPS Kalteng, 2019). 
Berdasarkan data yang ada pada prodi PLS (Dikmas) mahasiswa sebagian menerima beasiswa Bidikmisi dan penerima beasiswa lainnya, terutama mahasiswa yang berasal dari luar Kalimantan Tengah, namun yang paling banyak adalah mahasiswa kuliah dengan biaya secara mandiri berasal dari orang. Berdasarkan hasil wawancara kepada mahasiswa dijelaskan bahwa rata-rata status sosial orang tua mahasiswa berada pada kelas menengah ke bawah, dan yang paling banyak bekerja sebagai petani penyadap karet, berkebun buah-buahan dan menanam padi di lahan tadah hujan serta di sawah pasang surut, selain itu ada pula bekerja sebagai buruh.

2. Efektivitas Perkuliahan Jarak Jauh.

Sebagai akibat adanya wabah pandemi Covid-19 merambah masuk keseluruh wilayah Indonesia, maka semua pekerjaan terhanti yang dikarenakan orang merasa ketakutan untuk beraktivitas, orang takut berinteraksi dengan orang lain, merasa khawatir tertularnya virus Covid-19. Coronavirus adalah sekumpulan virus dari subfamili Orthocronavirinae dalam keluarga Coronaviridae dan ordo Nidovirales. Kelompok virus ini yang dapat menyebabkan penyakit pada burung dan mamalia, termasuk manusia. Pada manusia, coronavirus menyebabkan infeksi saluran pernapasan yang umumnya ringan, seperti pilek, meskipun beberapa bentuk penyakit seperti; SARS, MERS, dan COVID-19 sifatnya lebih mematikan. (Nur Rohim Yunus dan Annissa Rezki, 2020).

Ketakutan juga dirasakan oleh semua insan dunia perguruan tinggi pada saat dosen dan mahasiswa berinteraksi disaat perkuliahan berlangsung di kelas, agar pembelajaran tidak terhenti maka dosen berupaya dengan segala cara menciptakan model pembelajaran ditempuh agar pembelajaran tetap berjalan sesuai dengan standar yang dipersayaratkan dalam perencanaan pembelajaran yang sudah disusun dalam satu semester. Pembelajaran adalah proses interaksi mahasiswa dengan dosen dan sumber belajar pada suatu lingkungan belajar. (UU RI No.12 Tahun 20I2). Dosen dan mahasiswa program studi PLS (Dikmas) FKIP Universitas Palangka Raya telah mengikuti kebijakan yang dikeluarkan pemerintah sebagaimana dikutip dari jurnal Republika.Co.Id, Menteri Pendidikan dan Kebudayaan (Mendikbud) Nadiem Makarim menegaskan, bencana pandemi virus corona SARS-CoV2 (Covid-19) di Tanah Air membuat kegiatan belajar mengajar (KBM) di kelas terpaksa ditiadakan.

Adanya kebijakan yang mengharuskan kepada dosen dan mahasiswa semasa pendemi Covid-19 untuk melaksanakan kuliah jarak jauh dengan sistem daring ini, sesuai pula dengan UU RI Nomor 20 Tahun 2003 tentang Sistem Pendidikan Nasional Pasal I ayat (15) Pendidikan jarak jauh adalah pendidikan yang peserta didiknya terpisah dari pendidik dan pembelajarannya menggunakan berbagai sumber belajar melalui teknologi komunikasi, informasi, dan media lain. dan Peraturan Menteri Pendidikan dan Kebudayaan RI Nomor 24 Tahun 2012 tentang Penyelenggaraan Pendidikan Jarak Jauh Pada PendidikanTinggi, sebagaimana diatur Pasal I ayat (I) pendidikan jarak jauh yang selanjutnya disebut PJJ adalah pendidikan yang peserta didiknya terpisah dari peserta didik dan pembelajarannya menggunakan berbagai sumber melalui teknologi dan komunikasi, dan media lain.

Kebijakan ini tentu memberikan alternatif agar perkuliahan tetap berjalan dan memudahkan bagi dosen untuk menyampaikan materi perkuliahan kepada mahasiswa karena dosen cukup mengajar berada di rumah dan mahasiswapun juga menerima mareti kuliah berada di rumah, dengan menggunakan berbagai teknologi aplikasi yang ada diinternet seperti google meet, meeting zoom dan aplikasi lainnya. Namum dalam pelaksanaan perkuliahan jarak jauh menggunakan sistem daring selama wabah pandemi Covid-19, dosen memberikan materi perkuliahan kepada mahasiswa dilakukan menggunakan perangkat teknologi internet diantaranya menggunakan meeting zoom dan google meet. Berdasarkan hasil penelitian yang dilakukan kepada dosen dan mahasiswa program studi PLS (Dikmas) FKIP Universitas Palangka Raya banyak ditemukan masalah, namun secara garis besar terdapat dua kelemahan utama dalam penyelenggaraan perkuliahan:

a. Bagi Dosen.

Kegiatan proses pembelajaran jarak jauh (distance learning) dengan menggunakan sistem daring bagi dosen mengajar memiliki banyak kelemahan jika dibandingkan dengan pembelajaran biasa dengan tatap muka secara konvensional di kelas, berdasarkan hasil wawancara kepada dosen prodi PLS (Dikmas) yang mengajar pada semester genap TA 2019/2020 banyak dosen menemukan masalah dalam menyampaikan materi kuliah kepada mahasiswa, diantaranya dosen tidak bisa 
memberikan materi kuliah secara maksimal dikarenakan banyaknya hambatan dan ketidaksiapan mahasiswa untuk mengikuti perkuliahan, ini disebabkan selama wabah Covid-19 ini banyak mahasiswa pulang kampung ke desa berkumpul dengan orang tuanya, pernyataan ini disampaikan dosen pada saat wawancara. ... sebenarnya kita siap untuk mengajar dan siap memberikan materi kuliah. Namun walaupun kita sudah siap, akan tetapi kalau mahasiswanya tidak siap untuk menerima materi kuliah juga menjadi masalah, sehingga kita mengajar sia-sia. Kalaupun materi kuliah dapat mahasiswa terima itupun tidak bisa dilakukan secara maksinal karena keterbatasan dari pihak mahasiswa itu sendiri, untuk mengatasi keterbatasan ini kami juga membuat modul bahan ajar dan tugas kepada mahasiswa....

Jika mencermati pernyataan yang disampaikan dosen yang tidak bisa maksimal dalam menyampaikan materi pembelajaran secara online dengan jarak jauh menggunakan sistem daring ini kepada mahasiswa, tentu sangat mempengaruhi jalannya pembelajaran serta berdampak pula terhadap kelancaran proses kegiatan belajar mengajar ini. Firman dan Rahman, (2020), berpendapat bahwa pembelajaran yang dilaksanakan secara online juga memiliki tantangan tersendiri. Lokasi dosen dan mahasiswa yang terpisah saat melaksanakan pembelajaran membuat dosen tidak bisa memantau secara langsung aktivitas mahasiswa selama proses perkuliahan. Tidak ada jaminan bahwa mahasiswa benar-benar memperhatikan penjelasan yang diberikan oleh dosen. Padahal jika menyimak amanat UU Nomor I I Tahun 2008 tidak lain adalah untuk memudahkan dalam penyampaian informasi, sebagaimana Pasal 4 pemanfaatan teknologi informasi dan transaksi elektronik dilaksanakan dengan tujuan untuk. Hurup (a) mencerdaskan kehidupan bangsa sebagai bagian dari masyarakat informasi dunia.

Adanya keterbatasan mengajar jarak jauh ini memaksa dosen berinovasi membuat modul bahan ajar. Menurut Rogers (2003) inovasi adalah ide, ide dalam mengembangkan sebuah objek baru yang dilakukan manusia. Selain bahan ajar dosen juga memberi tugas kepada mahasiswa setiap kali perkuliahan yang disampaikan melalui group WhatsApp, dimana bahan ajar tersebut memiliki bobot setara dengan satu kali perkuliahan. Tugas yang dikerjakan mahasiswa hasilnya disampaikan melalui email atau handphone milik dosen, dan hasil koreksi dari tugas mahasiswa dibahas pada perkuliahan berikutnya sebelum dosen memberikan materi pokok bahasan baru. Tujuan diberikan modul bahan ajar dan tugas kepada mahasiswa ini tidak lain agar mahasiswa betul-betul mendalami, menguasai dan memiliki pengetahuan sehingga hasil belajar mahasiswa berkualitas.

\section{b. Bagi Mahasiswa.}

Mengingat kondisi mahasiswa prodi PLS (Dikmas) lebih banyak berasal dari putra daerah dan menyebar seluruh desa di Kalimantan Tengah yang memiliki luas wilayah I53.564,5 km2 atau 8,04 persen dari luas Indonesia. (BPS Kalteng, 2019). Dari jumlah luasan wilayah ini tentu tidak semuanya mendapat jaringan internet. Begitu pula kondisi mahasiswa yang berasal dari desa rata-rata orang tuanya tergolong dalam ekonomi kelas menengah ke bawah, banyak bekerja sebagai petani penyadap karet, berkebun buah-buahan dan menanam padi di lahan tadah hujan serta di sawah pasang surut, selain itu ada pula yang bekerja sebagai buruh. Nadia Fairuza Azzahra , (2020) berpendapat topografi Indonesia yang berupa kepulauan dan pegunungan membutuhkan pengadaan internet dan telekomunikasi seluler. Akan tetapi, jangkauan 4G kebanyakan terkonsentrasi di Pulau Jawa karena penyedia layanan telekomunikasi seluler, yang sangat bergantung pada pasar, tentu saja memprioritaskan daerah-daerah perkotaan ketimbang daerah pedesaan yang populasinya lebih sedikit. (Khatri, 2019); Selanjutnya Nadia Fairuza Azzahra, (2020) memperlihatkan tidak seimbangnya distribusi internet rumah tangga di seluruh wilayah yang ada. Kesenjangan konektivitas tersebut membuat siswa yang berasal dari keluarga prasejahtera di daerah pedesaan di luar Jawa sangat tidak diuntungkan.

Selama wabah pendemi Covid-19 ini mahasiswa pulang kampung disamping membantu orang tua bekarja, mahasiswa juga tetap mengikuti perkuliahan yang disampaikan oleh dosen secara jarak jauh dengan menggunakan sistem daring begitu pula bahan ajar berupa modul serta tugas yang disampaikan oleh dosen melalui group WhatsApp. Berdasarkan hasil wawancara kepada mahasiswa dikemukakan .... kami tetap mengikuti kuliah sesuai jadwal dan menerima materi kuliah dari dosen baik itu, berupa teori maupun tugas- 
tugas yang harus kami kerjakan. Namun kesulitan yang kami rasakan dalam mengikuti kuliah ini adalah sulitnya bagi kami mendapatkan sinyal internet, kadang supaya bisa kuliah kami harus berjalan berjam-jam mencari sinyal internet yang bagus, dan kadang menumpang di rumah penduduk, lagi pula kami kesulitan biaya untuk membeli paket data. Walaupun kami sudah menerima bantuan paket data dari pihak universitas namun paket data itu cepat habis karena dosen mengajar setiap mata kuliah rata-rata seratus menit, sehingga tidak cukup digunakan selama satu semester....

Kesulitan dan hambatan yang dialami mahasiswa khususnya bagi mereka yang selama Covid-19 ini tinggal dan berada di desa, tentu membuat kegiatan proses perkuliahan yang diterima tidak maksimal, kondisi demikian akibatnya bisa mahasiswa menjadi pasif, pasrah, tidak konsentrasi dan malas untuk mengikuti kuliah. Szpunar, Moulton, \& Schacter, (2013) sebagaimana dikutip Firman dan Rahman, (2020) dijelaskan bahwa mahasiswa menghayal lebih sering pada perkuliahan online dibandingkan dengan perkuliahan tatap muka. Selanjutnya Khan (20I2); Firman dan Rahman, (2020) Untuk itu menyarankan bahwa perkuliahan online harus dilaksanakan dalam waktu yang tidak lama karena mahasiswa kesulitan mempertahankan konsentrasi jika perkuliahan secara online dilaksanakan lebih dari satu jam.

\section{KESIMPULAN}

Kegiatan proses perkuliahan pada semester Genap Tahun Akademik 2019/2020 selama pendemi Covid-19, bagi dosen dan mahasiswa prodi PLS (Dikmas) FKIP Universitas Palangka Raya, sejak adanya kebijakan pemerintah yang merubah sistem pembelajaran semula dilaksanakan pola lama dengan tatap muka di kelas antara dosen dan mahasiswa berubah menjadi pembelajaran jarak jauh online menggunakan sistem daring. Berdasarkan analisis data ditemukan bahwa pelaksanaan perkuliahan yang dilakukan jarak jauh secara online dengan menggunakan sistem daring dari dosen kepada mahasiswa khususnya mahasiswa yang selama ini berada di desa kampung halamannya tidak dapat dilaksanakan secara maksimal, ini dikarenakan antara lain penerimaan sinyal internet di desa sangat terbatas dan banyaknya pengeluaran biaya bagi mahasiswa untuk membeli paket data internet.

\section{DAFTAR PUSTAKA}

Azzahra, Nadia Fairuza (2020). Mengkaji Hambatan Pembelajaran Jarak Jauh di Indonesia di Masa Pandemi Covid-19. Center for Indonesian Policy Studies (CPIPS).

Badan Pusat Statistik. (2019). ProvinsiKalimantan Tengah Dalam Angka 2019. Palangka Raya: CV. APP Digital Printing

Creswell, W. John. (20I7). Research Design. Pendekatan Metode Kualitatif, Kuantitatif, dan Campuran. (Terjemahan Achmad Fawaid dan Rianayati Kusmini Pancasari). Yogyakarta: Pustaka Pelajar.

Firman dan Rahman, Sari Rahayu. (2020). Pembelajaran Online di Tengah Pandemi Covid-19. Indonesian Journal of Educational Science (IJES).

Khasanah, Dian Ratu Ayu Uswatun, Pramudibyanto, Hascaryo, \& Widuroyekti, Barokah Widuroyekti. (2020). Pendidikan Dalam Masa Pandemi Covid-19. Jurnal Sinestesia, I0(I), 4I-48.

Lincoln, Yvonna S, dan Egon G. Guba. (1985). Naturalistic Inquiry. California: Sage Publication Ltd.

Makarim, Nadiem. (2020). Mendikbud: Perguruan Tinggi di Semua Zona Dilarang Kuliah Tatap Muka. Jakarta: Kompas.com - 16/06/2020

Miles, B. Matthte, Huberman, A. Michaell, dan Saldana, Johnny. (20I4). Quaitative Data Analysis. A. Methods Sourcebook, Edition 3. London: SAGE Publication,Inc.

Novita, Diana, \& Hutasuhut, Addiestya. Rosa. (2020). Plus Minus Penggunaan AplikasiAplikasi Pembelajaran Daring Selama Pandemi Covid-19. Medan: Unimed.

Rogers, M. Everett. (2003). Diffusion of Innovations. Fifth Edition. New York, USA: The Free Press, A Division of Simon \& Schuster, Inc.

Strauss, Anselm \& Corbin, Juliet. (20I7). Dasardasar Penelitian Kualitatif. Tatalangkah dan Teknik-teknik Teoritisasi Data. Cetakan V. Yogyakarta: Pustaka Pelajar.

Yunus, Nur Rohim, \& Rezki Annissa. (2020). Kebijakan Pemberlakuan Lock Down Sebagai Antisipasi Penyebaran Corona Virus Covid19. Jakarta: Salam Jurnal Sosial dan Budaya Syar-i.

--------, Undang-undang Dasar Negara Republik Indonesia Tahun 1945. Jakarta: Setneg. 
---------(2008) Undang-undang RI Nomor II Tahun 2008 Tentang Informasi Dan Transaksi Elektronik. Jakarta: Setneg.

-(2003). Undang-undang Nomor 20 Tahun 2003 Tentang Sistem Pendidikan Nasional. Jakarta: Depdikbud.

(2012). Undang-Undang RI Nomor 12 Tahun 2012 Tentang Pendidikan Tinggi. Jakarta: Sesneg.
-(20I2). Peraturan Mendikbuda RI Nomor 24 Tahun 2012 Tentang Penyelenggaraan Pendidikan Jarak Jauh Pada PendidikanTinggi. Jakarta: Sesjen Depdikbud. 